\title{
PKM PENDIRIAN BANK SAMPAH PADA KELOMPOK IBU RUMAH TANGGA, JANDA, DAN LANSIA DI DESA DEKETAGUNG, KECAMATAN SUGIO, KABUPATEN LAMONGAN
}

\author{
Muryani Muryani ${ }^{1}$, Shochrul Rohmatul Ajija ${ }^{2}$, Riris Diana Rachmayanti ${ }^{3}$, Angga \\ Erlando ${ }^{4}$ \\ Universitas Airlangga, Surabya, Indonesia ${ }^{1234}$
}

\begin{abstract}
The community service program that has been implemented in the village of Deketagung, Sugio District, Lamongan Regency has a design activity to form a waste bank to empower housewives, widows and the elderly. This community empowerment also aims to improve environmental conditions and improve the economy of the village community. Activities that have been carried out include: the socialization of the formation of a garbage bank to groups of housewives, the elderly and widows, forming groups to manage waste at the household level, designing incentives for the exchange of recyclable waste, and counting the results of garbage collected, evaluation recording of garbage banks, and Focus Group Discussion (FGD. The existence of a community service program through mentoring the formation of a garbage bank in the village of Deketagung, is expected to be able to improve the economy of the people of the village of Deketagung through waste management and creating a clean environment.
\end{abstract}

Keywords: Trash Bank; housewives; widow, elderly, empowerment, environment

\section{Abstrak}

Program pengabdian masyarakat yang telah dilaksanakan di desa Deketagung, Kecamatan Sugio, Kabupaten Lamongan memiliki design kegiatan membentuk bank sampah untuk memberdayakan ibu rumah tangga, janda, dan lansia. Pemberdayaan masyarakat ini juga bertujuan untuk memperbaiki kondisi lingkungan serta meningkatkan perekonomian masyarakat desa tersebut. Kegiatan yang telah dilakukan meliputi: sosialisasi pembentukan bank sampah pada kelompok ibu rumah tangga, lansia, dan janda, membentuk kelompok-kelompok untuk mengelola sampah di tingkat rumah tangga, mendesain insetif pertukaran sampah yang bisa didaur ulang, dan menghitung hasil sampah yang terkumpul, evaluasi pencatatan bank sampah, dan Focus Group Discussion (FGD. Adanya program pengabdian masyarakat melalui pendampingan pembentukan bank sampah di desa Deketagung, diharapkan mampu meningkatkan perekonomian masyarakat desa Deketagung melalui pengelolaan sampah dan mewujudkan lingkungan bersih.

Kata Kunci: Bank Sampah, Ibu Rumah Tangga, Janda, Lansia, Pemberdayan, Lingkungan

\section{PENDAHULUAN}

Deketagung merupakan satu dari 21 salah satu desa yang berada di Kecamatan Sugio, Kabupaten Lamongan. Desa Deketagung sendiri bukan termasuk dalam kategori desa tertinggal karena semua fasilitas penunjang sudah lengkap seperti sekolah dan polindes (puskesmas). Jumlah penduduk yang ada didesa deketagung berjumlah 3.600 an jiwa yang tersebar dalam 4 (empat) dusun, yaitu Dusun Deket, Dusun Kedungsogo, Dusun Juwet Raya, dan Dusun Kedunggadung.

Mata pencaharian utama warga di daerah tersebut adalah bertani. Mereka yang keadaan ekonomi mampu biasanya memiliki lahan sawah yang luas, sehingga hasil panen melimpah. Sedangkan mereka dengan ekonomi menengah ke bawah rata-rata mempunyai sawah yang tidak cukup luas dan kebanyakan mereka adalah buruh tani, bahkan beberapa tidak memiliki lahan sawah sama sekali (hanya sebagai buruh tani). Mereka yang melakukan aktivitas bertani atau ke sawah tidak hanya laki-laki saja (suami) akan tetapi

\footnotetext{
${ }^{1}$ Email: muryani2008@yahoo.co.id
} 
juga perempuan (istri). Dalam segi pendapatan para buruh tani, tenaga laki-laki yang biasanya di bayar Rp. 80.000 (delapan puluh ribu rupiah) dalam sehari dan Rp. 40.000 (empat puluh ribu rupiah) bagi tenaga perempuan. Hal ini dikarenakan pembagian pekerjaan yang relative berbeda dimana pekerjaan perempuan biasanya lebih ringan seperti menanam atau mencabut rumput. Namun demikian, kegiatan bertani tidaklah dilakukan setiap hari, terutama bagi buruh tani, tenaganya paling banyak dibutuhkan saat musim tanam tiba dan saat musim panen. Sisanya, yaitu saat masa perawatan tidak dibutuhkan banyak tenaga kerja, sehingga sebagian dari mereka (buruh tani) menggangur.

Hidup di daerah pedesaan dan dalam lingkungan pertanian tidak menjadikan semua masyarakatnya bisa bercocok tanam, atau bahkan tidak semuanya bisa menjadi buruh tani terutama bagi perempuan (Muryani, 2016), banyak dari mereka yang hanya menjadi ibu rumah tangga saja. Selain itu, ada pula para janda yang tidak memiliki keahlian dan tidak bisa bekerja menjadi buruh di sawah, dan mereka para lansia yang tidak lagi kuat bekerja berat, akhirnya menjadi pengangguran di desa. Di sisi lain, permasalahan yang muncul di Desa Deketagung adalah terkait sampah. Masyarakat di desa ini masih mengolah sampah secara konvensional yaitu dengan membakar ataupun membuang begitu saja di kebun atau sawah. Ditambah lagi banyaknya fasilitas umum seperti sekolah, pasar, dan tempat wisata berupa waduk yang semakin menambah tingginya kuantitas sampah baik organik maupun non organik di kawasan tersebut.

Sebenarnya, di desa ini sudah terdapat beberapa pengepul sampah terutama untuk sampah dari plastic. Salah satunya adalah milik Ahmad Syarifudin Hidayat, salah satu mahasiswa aktif Prodi S1 Akuntansi Fakultas Ekonomi dan Bisnis Universitas Airlangga. Keprihatinan terhadap banyaknya jumlah sampah di desanya membuat mahasiswa tersebut bergerak dan mendirikan usaha pengolahan daur ulang sampah plastik jenis PET (Polyethylane Terepthalate) atau jenis botol plastic di kebun rumahnya sejak Desember 2015.

Oleh karena itu kegiatan ini selanjutnya akan menjadikan Ahmad Syarifudin Hidayat sebagai mitra yang nantinya akan membantu memberikan layanan pengolahan sampah terutama dari botol plastic yang sudah dihimpun oleh bank sampah yang didirikan ibu-ibu, janda, dan lansia wanita di desa ini. Dengan demikian bank sampah yang akan terbentuk akan menjadi lebih sustainable karena ada mitra yang punya power untuk menggerakkan masyarakat di desa ini. Berdasarkan analisis situasi tersebut, maka prioritas masalah yang dihadapi ibu-ibu, janda, dan lansia perempuan di Desa Deketagung, Kecamatan Sugio, Kabupaten Lamongan adalah sebagai berikut: (1) Aspek sosial budaya seperti: kurangnya kesadaran membuang sampah pada tempatnya, dan kurangnya pengetahuan mengenai budaya hidup sehat; (2) Aspek produksi seperti: kurangnya pemahaman dan keterampilan 3 R (Reduce, Reuse, Recycle) sampah rumah tangga; kurangnya pemahaman dan keterampilan dalam mengolah sampah basah menjadi komposter, dan tidak adanya sarana dan prasarana untuk pembuatan komposter; (3) Aspek manajemen usaha sepert: kurangnya pemahaman mengenai manajemen pengelolaan bank sampah, kurangnya pemahaman mengenai pembukuan sederhana bank sampah, dan kurangnya pemahaman mengenai penghitungan laba rugi dan neraca bank sampah.

\section{MATERI DAN METODE PELAKSANAAN}

Metode pendekatan yang akan digunakan dalam program ini adalah sebagai berikut: 


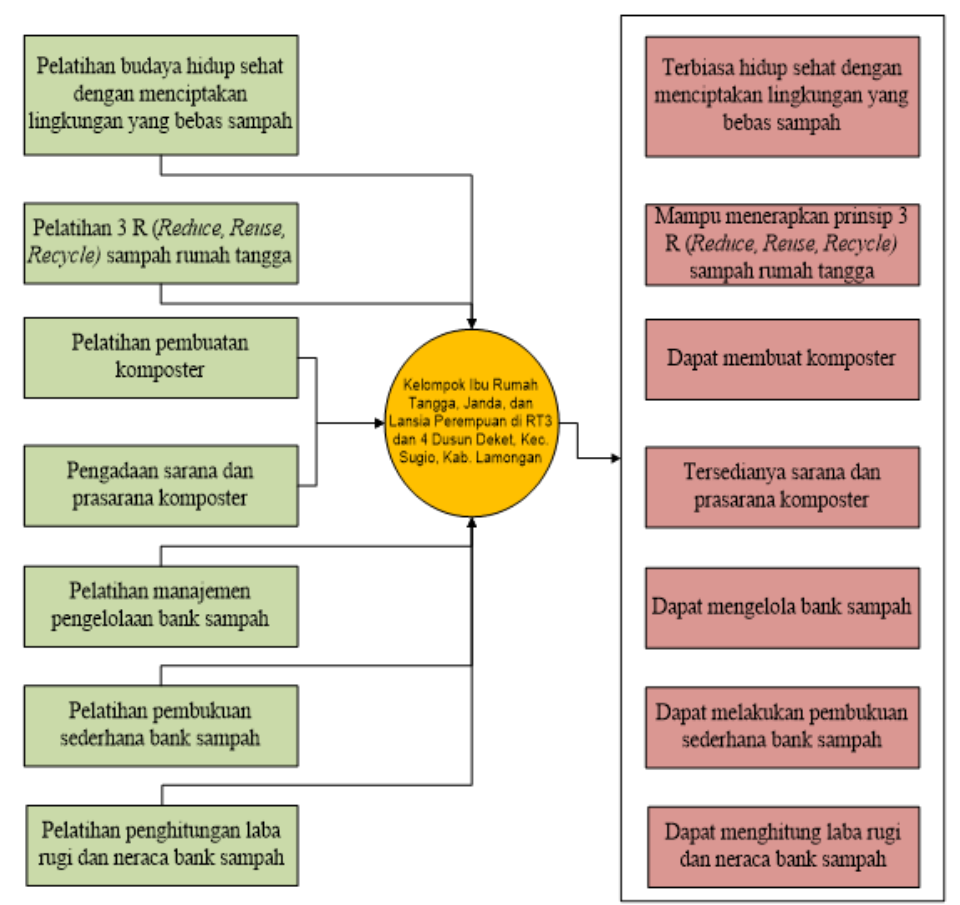

\section{Partisipasi Mitra}

Gambar 1. Metode Pendekatan

Partisipasi mitra dalam kegiatan ini diharapkan warga di Desa Deketagung Kecamatan Sugio, Kabupaten Lamongan dapat memberikan sampah maupun barang yang sudah tidak digunkan kepada beberapa pengepul sampah terutama untuk sampah dari plastic. Salah satunya adalah milik Ahmad Syarifudin Hidayat, salah satu mahasiswa aktif Prodi S1 Akuntansi Fakultas Ekonomi dan Bisnis Universitas Airlangga. Keprihatinan terhadap banyaknya jumlah sampah di desanya membuat mahasiswa tersebut bergerak dan mendirikan usaha pengolahan daur ulang sampah plastik jenis PET (Polyethylane Terepthalate) atau jenis botol plastic di kebun rumahnya sejak Desember 2015.

Oleh karena itu kegiatan ini selanjutnya akan menjadikan Ahmad Syarifudin Hidayat sebagai mitra yang nantinya akan membantu memberikan layanan pengolahan sampah terutama dari botol plastic yang sudah dihimpun oleh bank sampah yang didirikan ibuibu, janda, dan lansia wanita di desa ini. Dengan demikian bank sampah yang akan terbentuk akan menjadi lebih sustainable karena ada mitra yang punya power untuk menggerakkan masyarakat di desa ini.

\section{Evaluasi Pelaksanaan}

Langkah evaluasi pelaksanaan program dan keberlanjutan program di lapangan setelah kegiatan PKM selesai dilaksanakan adalah:

a. Mengevaluasi kehadiran, kemampuan, keaktifan, para ibu rumah tangga, janda dan lansia tentang pembuangan sampah di bank sampah;

b. Mengevaluasi kehadiran, kemampuan, keaktifan, para ibu rumah tangga, janda dan lansia tentang pemahaman pengelolaan bank sampah.

\section{HASIL DAN PEMBAHASAN}

Rencana Solusi Kegiatan, Target Program, dan Capaian Target Luaran

Sampah merupakan permasalahan besar yang dialami oleh seluruh negara di belahan dunia, termasuk Indonesia. Indonesia memiliki lebih dari 240 juta jiwa penduduk dan 
menghasilkan setidaknya 1ton sampah perhari. Sampah terbanyak yang dihasilkan Indonesia adalah berasal dari sampah rumah tangga. Sampah rumah tangga yang umum ditemui adalah sampah plastik food and beverage, terutama sampah plastik. Sampah tersebut tidak dapat diuraikan selama kurang dari 200 tahun lamanya. Sehingga penanganan sampah menjadi faktor utama dalam mengatasi permasalahan sampah yang terjadi di Indonesia. Apabila tidak ditangani sedini mungkin, tidak dapat dimungkinkan tahun 2050 sampah tidak hanya akan menjadi gunung di daratan, membuat dangkal sungai dan menyumbat aliran air sungai, akan tetapi sampah juga akan memenuhi perairan di laut bebas bahkan jumlahnya diprediksi akan lebih banyak dibandingkan dengan jumlah ikan yang ada di laut (WHO, 2017).

Menurut Muryani (2017) Penanganan sampah tidak hanya menjadi tanggung jawab pemerintah. Masyarakat wajib turut serta dalam penanganan sampah terutama sampah yang ada di lingkungan sekitar. Sementara itu, penanganan sampah dapat dibedakan menjadi dua tahap, 1) tahap pencegahan dan 2) tahap pengelolaan. Tahap yang dapat dilakukan oleh masyarakat dalam menangani permasalahan sampah adalah tahap pencegahan. Penanganan sampah oleh masyarakat dalam tahap pencegahan bisa dilakukan dengan banyak cara. Salah satu cara yang dapat dilakukan adalah dengan menggerakkan masyarakat sekitar untuk menumbuhkan rasa cinta kepada lingkungan dan tidak membuang sampah sembarangan. Mengingat sampah yang dibuang sembarangan akan meningkatkan risiko permasalahan lingkungan yang lebih komplek, seperti banjir dan kerusakan ekosistem lingkungan. Sehingga metode yang tepat untuk menggerakkan kesadaran masyarakat agar menjaga lingkungan dan membuang sampah dengan tepat adalah dengan membuat kelompok kerja 'bank sampah.

Bank sampah merupakan sebuah gerakan masyarakat yang berada di lingkungan RT yang beranggotakan masyarakat sekitar tidak hanya ibu PKK tetapi juga seluruh elemen masyarakat Desa Dekatagung Kecamatan Sugio Kabupaten Lamongan. Bank sampah ini tidak hanya bertujuan untuk menyadarkan masyarakat agar tidak membuang sampah sembarangan. Namun juga menjadikan sampah sebagai salah satu sumber manfaat ekonomi bagi masyarakat. Secara teknis, bank sampah merupakan kelompok kerja yang dibentuk masyarakat untuk mengakomodir sampah plastik yang dihasilkan rumah tangga untuk dikumpulkan dan dipilah sesuai dengan jenis sampahnya. Apabila sudah terkumpul, maka sampah tersebut akan dijual dan hasil penjualan akan diberikan secara adil kepada anggota menurut imbal jasa atau jumlah sampah yang telah dikumpulkan oleh setiap anggota.

Berdasarkan pada ulasan tersebut dan pemaparan fakta masalah yang dijabarkan pada Bab 1, maka solusi yang akan ditawarkan berdasarkan permasalahan yang ada adalah sebagai berikut:

Tabel 2. Rencana Solusi Kegiatan dan Target Program

\begin{tabular}{|c|c|c|c|}
\hline No & Masalah & Solusi & Target \\
\hline 1 & Aspek Sosial Budaya & & \\
\hline $\mathrm{a}$ & $\begin{array}{l}\text { Kurangnya kesadaran } \\
\text { membuang sampah pada } \\
\text { tempatnya }\end{array}$ & $\begin{array}{l}\text { Pelatihan budaya hidup } \\
\text { sehat dengan menciptakan } \\
\text { lingkungan yang bebas } \\
\text { sampah }\end{array}$ & $\begin{array}{l}\text { Peserta semakin sadar } \\
\text { lingkungan dengan } \\
\text { membuang sampah pada } \\
\text { tempatnya }\end{array}$ \\
\hline$b$ & $\begin{array}{l}\text { Kurangnya pengetahuan } \\
\text { mengenai budaya hidup sehat }\end{array}$ & & $\begin{array}{l}\text { Peserta memahami dan } \\
\text { membiasakan budaya } \\
\text { hidup sehat }\end{array}$ \\
\hline
\end{tabular}




\begin{tabular}{|c|c|c|c|}
\hline No & Masalah & Solusi & Target \\
\hline 2 & Aspek Produksi & & \\
\hline $\mathrm{a}$ & $\begin{array}{l}\text { Kurangnya pemahaman dan } \\
\text { keterampilan } 3 \mathrm{R} \text { (Reduce, } \\
\text { Reuse, Recycle) sampah } \\
\text { rumah tangga }\end{array}$ & $\begin{array}{l}\text { Pelatihan } 3 \mathrm{R} \text { (Reduce, } \\
\text { Reuse, Recycle) sampah } \\
\text { rumah tangga }\end{array}$ & $\begin{array}{l}\text { Peserta memahami dan } \\
\text { terampil dalam } 3 \mathrm{R} \\
\text { (Reduce, Reuse, Recycle) } \\
\text { sampah rumah tangga }\end{array}$ \\
\hline $\mathrm{b}$ & $\begin{array}{l}\text { Kurangnya pemahaman dan } \\
\text { keterampilan dalam mengolah } \\
\text { sampah basah menjadi } \\
\text { komposter }\end{array}$ & $\begin{array}{l}\text { Pelatihan pembuatan } \\
\text { komposter }\end{array}$ & $\begin{array}{l}\text { Peserta dapat membuat } \\
\text { komposter dari sampah } \\
\text { basah rumah tangga }\end{array}$ \\
\hline $\mathrm{c}$ & $\begin{array}{l}\text { Tidak adanya sarana dan } \\
\text { prasarana untuk pembuatan } \\
\text { komposter }\end{array}$ & $\begin{array}{l}\text { Pengadaan sarana dan } \\
\text { prasarana komposter }\end{array}$ & $\begin{array}{l}\text { Tersedianya sarana dan } \\
\text { prasarana komposter }\end{array}$ \\
\hline 3 & Aspek Manajemen Usaha & & \\
\hline $\mathrm{a}$ & $\begin{array}{l}\text { Kurangnya pemahaman } \\
\text { mengenai manajemen } \\
\text { pengelolaan bank sampah }\end{array}$ & $\begin{array}{l}\text { Pelatihan manajemen } \\
\text { pengelolaan bank sampah }\end{array}$ & $\begin{array}{l}\text { Peserta dapat memahami } \\
\text { manajemen pengelolaan } \\
\text { bank sampah dengan baik }\end{array}$ \\
\hline $\mathrm{b}$ & $\begin{array}{l}\text { Kurangnya pemahaman } \\
\text { mengenai pembukuan } \\
\text { sederhana bank sampah }\end{array}$ & $\begin{array}{l}\text { Pelatihan pembukuan } \\
\text { sederhana bank sampah }\end{array}$ & $\begin{array}{l}\text { Peserta memahami } \\
\text { pembukuan sederhana } \\
\text { bank sampah dengan baik }\end{array}$ \\
\hline $\mathrm{c}$ & $\begin{array}{l}\text { Kurangnya pemahaman } \\
\text { mengenai penghitungan laba } \\
\text { rugi dan neraca bank sampah }\end{array}$ & $\begin{array}{l}\text { Pelatihan penghitungan laba } \\
\text { rugi dan neraca bank } \\
\text { sampah }\end{array}$ & $\begin{array}{l}\text { Peserta memahami } \\
\text { penghitungan laba rugi } \\
\text { dan neraca bank sampah } \\
\text { dengan baik }\end{array}$ \\
\hline
\end{tabular}

Sementara itu, untuk target luaran dari program PKM ini adalah sebagai berikut:

Tabel 3. Rencana Capaian Target Luaran

\begin{tabular}{|c|c|}
\hline NoJenis Luaran & $\begin{array}{l}\text { Indikator } \\
\text { Capaian }\end{array}$ \\
\hline \multicolumn{2}{|l|}{ Luaran wajib } \\
\hline 1 Publikasi ilmiah pada Jurnal Pengmas Universitas Airlangga & Published \\
\hline 2 Publikasi pada media masa cetak/online/repocitory PT & $\begin{array}{l}\text { Proses } \\
\text { editing/sudah } \\
\text { terbit }\end{array}$ \\
\hline $\begin{array}{l}3 \text { Peningkatan daya saing (peningkatan kualitas, kuantitas, serta nilai } \\
\text { tambah barang, jasa, diversifikasi produk, atau sumber daya lainya ) }\end{array}$ & $\begin{array}{l}\text { Terdaftar } \\
\text { /granted }\end{array}$ \\
\hline 4 Peningkatan penerapan iptek di masyarakat (mekanisasi, IT, dan & Besar \\
\hline Manajemen) & Peningkatan \\
\hline $\begin{array}{l}5 \text { Perbaikan tata nilai masyarakat (seni budaya, sosial, politik, } \\
\text { keamanan, ketentraman, pendidikan, kesehatan) }\end{array}$ & $\begin{array}{l}\text { Sudah } \\
\text { Dilaksanakan }\end{array}$ \\
\hline \multicolumn{2}{|l|}{ Luaran Tambahan } \\
\hline 1 Jasa;rekayasa sosial, metode, atau sistem, produk/barang & Penerapan \\
\hline 2 Buku ber ISBN & Draft \\
\hline
\end{tabular}

\section{Hasil Pelaksanaan Kegiatan}

Hasil Proses dan Pelaksanaan Bank Sampah di Desa Deketagung adalah sebagai berikut: 
1. Kegiatan pertama yang dilakukan oleh pihak mitra kepada obyek pengabdian masyarakat adalah sosialisasi awal terkait bank sampah. Sosialisasi ini bertujuan untuk memberikan pengenalan dan pengetahuan dasar mengenai urgensi pembentukan bank sampah di desa Deketagung, Kabupaten Lamongan. Pada kegiatan sosialisasi ini, terdapat beberapa poin penting yang disampaikan, yaitu:

i. Penjelasan umum tentang definisi Bank Sampah

ii. Penjelasan alur pengelolaan sampah pada sistem bank sampah

iii. Pembagian hasil pengelolaan sampah

Sosialisasi ini dilakukan selama 2 hari, yaitu pada tanggal 30 Juni 2018 hingga 01 Juli 2018 di salah satu rumah warga desa Deketagung. Sosialiasi ini dihadiri oleh sekitar 30 warga yang terdiri oleh kepala dusun, ketua program green and clean dan ketua Rt 003 dan Rt 005 dusun deket agung, desa deket agung kabupaten Lamongan.

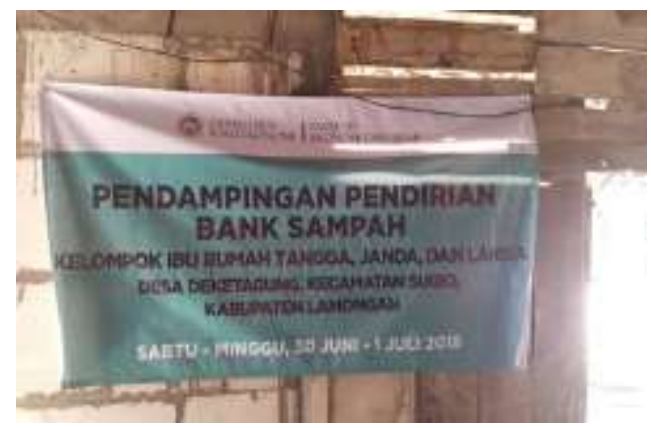

Gambar 2. Spanduk Kegiatan Pendampingan Pendirian Bank Sampah

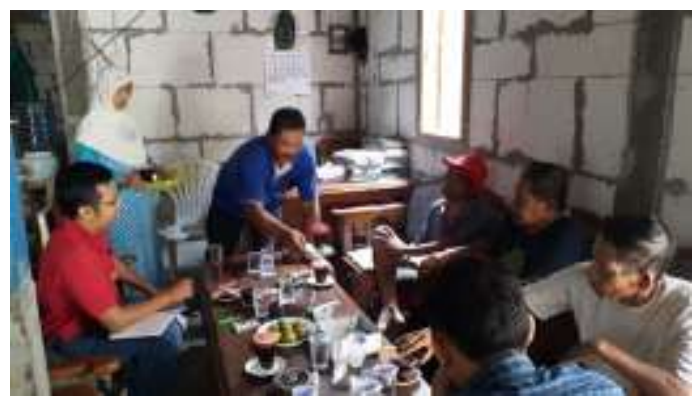

Gambar 3. Kegiatan Sosialisasi Pendirian Bank Sampah

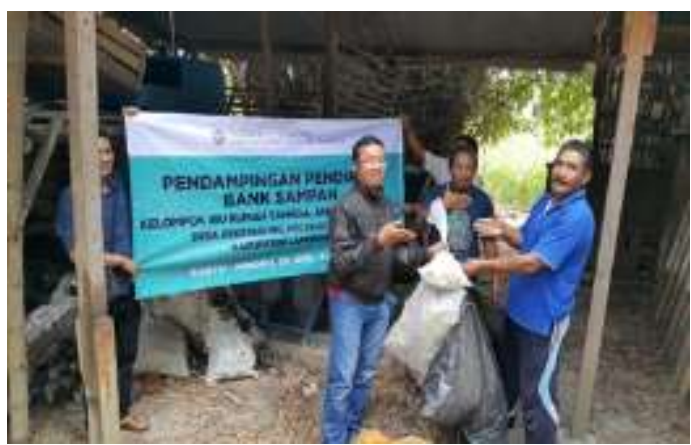

Gambar 4. Kegiatan Sosialisasi Pendirian Bank Sampah 


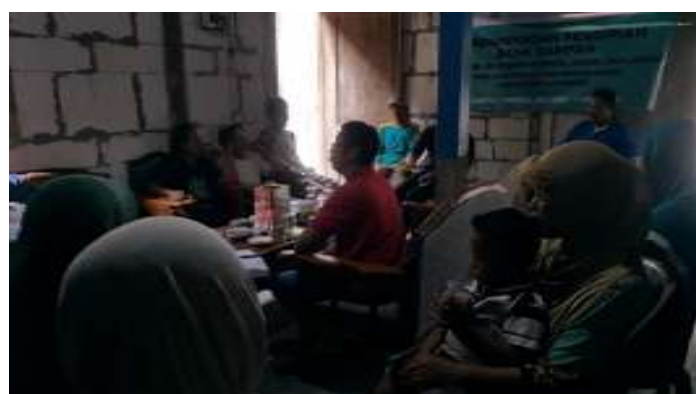

Gambar 5. Kegiatan Sosialisasi Pendirian Bank Sampah

2. Setelah proses sosialisasi dilakukan oleh pihak mitra, kegiatan kedua yang dilakukan pada pendampingan tersebut adalah juga dibentuk kelembagaan beserta kelompokkelompok untuk mengelola sampah di tingkat rumah tangga. Kelembagaan yang dibentuk memiliki struktur yang sederhana, yang beranggotakan ketua, sekretaris, dan bendahara. Jumlah kelompok yang disepakati adalah 10-15 kelompok, di mana masing-masing kelompok beranggotakan maksimal 5 orang. Pada struktur organisasi tersebut, tugas dari masing-masing pengurus adalah sebagai berikut:

a) Tanggung Jawab Ketua:

i. Membuat SIUP

ii. Merancang dan Merencanakan ADRT

iii. Merancang Pedoman dan peraturan Bank Sampah

iv. Merancang dan Menghitung pembentukan usaha

b) Tanggung jawab Sekretaris:

i. Membuat ADRT Bank Sampah

ii. Membuat surat permohonan pembentukan usaha

c) Tanggung jawab Bendahara:

i. Mengelola Keuangan

ii.Membuat pembukuan keuangan (pencatatan transaksi sampah botol, kertas yang terkumpul oleh warga)

Terdapat dua struktur yang telah terbentuk, yaitu kelompok RT 4 dan RT 5, berikut adalah susunannya:

a) Struktur RT 4 terdiri dari Ketua (Pak Kasdi), Sekretaris (Pak Muhamad Nurhadi) dan Bendahara (Bu Siti Rumelah).

b) Struktur RT 5 terdiri dari Ketua (Pak Budi Utomo), Sekretaris (Anurin) dan Bendahara (Pak H. Dahyono).

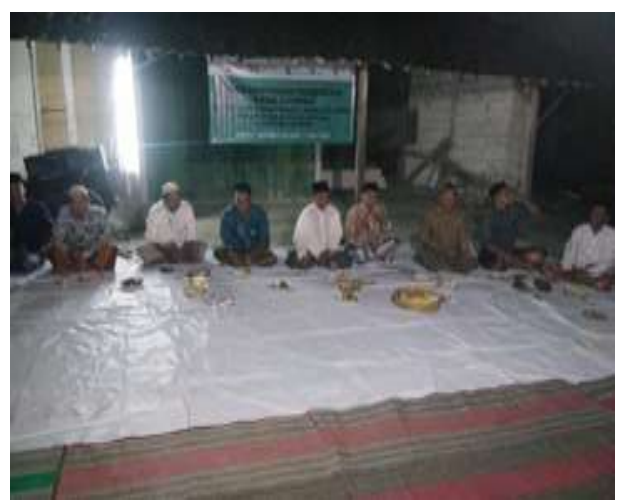

Gambar 6. Kegiatan Pembagian Kelompok Pengelola Sampah. 
Kelompok kecil tersebutlah yang akan berperan dalam pemilahan sampah sebelum disetorkan ke bank sampah. Sesuai yang disepakati oleh warga dan pihak mitra, sampah dipilah menjadi 3 jenis, yaitu: (1) sampah plastik; (2) sampah organik; dan (3) sampah kertas. Sebagai tambahan, pada tahapan ini juga telah disepakati tempat pengumpulan sampah, yakni di belakang rumah kepala Dusun.

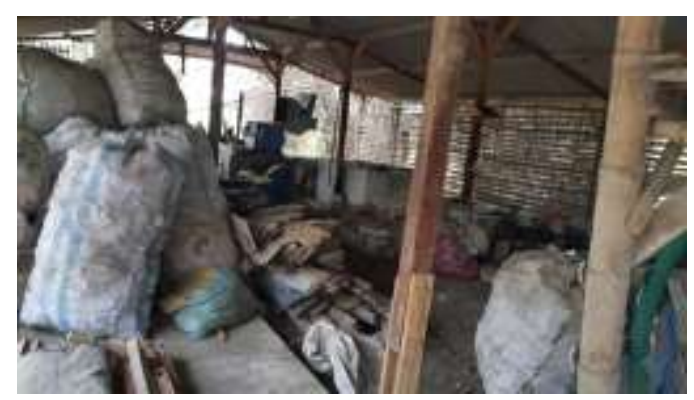

Gambar 7. Tempat Pengumpulan Sampah

3. Kegiatan selanjutnya yang dilakukan adalah mendesain insentif pertukaran sampah. Insentif penukaran sampah yang dilakukan pada bank sampah tidak selalu berupa uang, namun dapat berupa barang lain yang disepakati oleh warga setempat. Pada bank sampah yang akan dibentuk di desa Deketagung ini, insentif pertukaran sampah yang disepakati adalah bawang merah dan bawang putih. Hal ini disebabkan karena dua barang tersebut merupakan bahan kebutuhan pokok rumah tangga. Untuk mekanisme pertukaran yang disepakati adalah $1 \mathrm{~kg}$ sampah ditukarkan 10 gram bawang merah dan bawang putih.

4. Kegiatan pendampingan yang ketiga dilakukan pada tanggal 14 Oktober 2018 oleh salah satu tim inisiator kelompok kerja bank sampah. Secara histori, adapun agenda pendampingan bank sampah yang telah dilaksanakan di antaranya, pendampingan pertama telah dilalui dengan penyuluhan pentingnya pengelolaan sampah di lingkungan masyarakat. Pendampingan kedua dilalui dengan pembentukan dan peresmian kelompok kerja bank sampah. Perlu menjadi catatan, bahwa setiap tahap pendampingan akan selalu menjadi evaluasi baik kami sebagai inisiator maupun anggota bank sampah untuk pengembangan kelompok kerja bank sampah agar lebih maju kedepannya

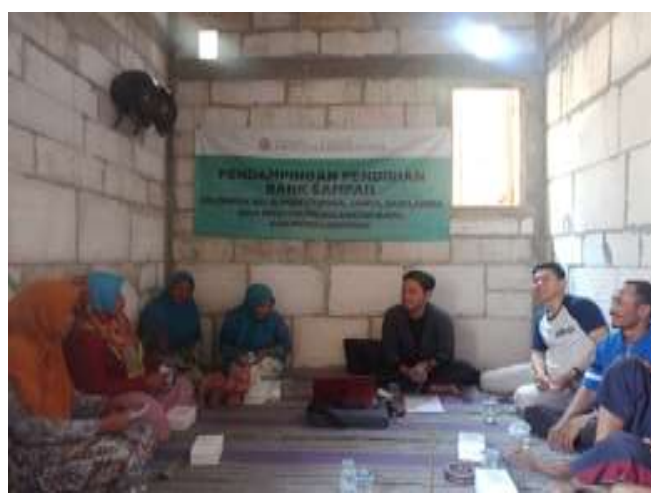

Gambar 8. Kegiatan Pendampingan Ketiga Bank Sampah

Pada pendampingan ketiga ini, tim inisiator melihat perkembangan dan hasil kerja dari kelompok kerja bank sampah. Pada tahap ini, agenda tim inisiator adalah menghitung hasil sampah yang terkumpul selama dua bulan program ini berjalan. Sementara itu, 
dikarenakan selama program kerja ini berjalan masih tidak ada sistim pencatatan perolehan sampah yang komprehensif, maka pada hari ini tim inisiator juga berkesempatan memberikan kepada setiap anggota kelompok kerja bank sampah buku catatan sampah sebagai media pencatatan yang komprehensif dan berkelanjutan. Dan berkesempatan mensosialisasikan sistim pencatatan sampah ke dalam buku catatan sampah tersebut. Sehingga hasil perolehan sampah setiap anggota dapat dihitung secara pasti karena imbal hasil atau manfaat ekonomi yang akan dibagikan kepada anggota dihitung berdasarkan pada jumlah sampah yang dikumpulkan.

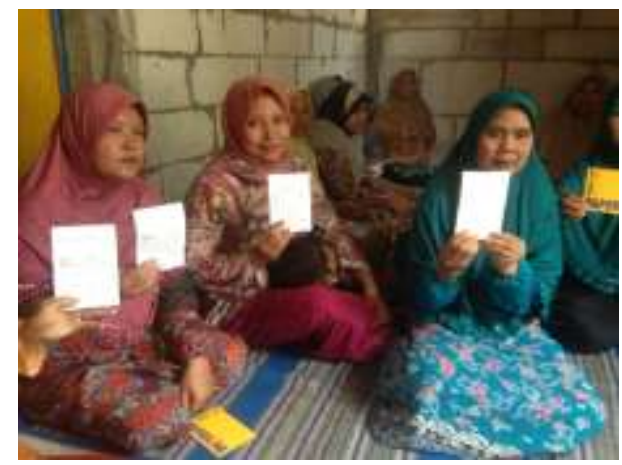

Gambar 9. Sosialisasi Sistem Pencatatan Bank Sampah

Selama dua bulan berjalan, program bank sampah dapat dikatakan berjalan dengan baik dan sesuai harapan. Hal ini dapat diketahui dengan melihat jumlah sampah yang dikumpulkan angoota sangat banyak dan frekuensi anggota yang cukup tinggi sebagai pengukur antusiasme anggota dalam melaksanakan program bank sampah. Setelah melalui tahap perhitungan, dapat diketahui rata-rata jumlah atau berat sampah yang dikumpulkan masyarakat mencapai $2-3 \mathrm{~kg}$ sampah per anggota. Perlu diketahui, sampah yang dikumpulkan anggota sangat beragam, mulai dari sampah an-organik seperti kardus, botol plastik, baskom pecah, hingga sampah organik seperti nasi aking. Sementara itu, dalam satu minggu diketahui frekuensi anggota dalam menyetorkan sampah dapat dilakukan hingga tiga kali penyetoran.

Seperti yang telah dijelaskan sebelumnya, bahwa pada setiap kali pendampingan tim inisiator akan selalu mengadakan evaluasi. Maka pada akhir sesi pendampingan ketiga ini, tim inisiator mengadakan Forum Group Discussion (FGD). FGD dilakukan untuk mengetahui kendala yang dihadapi anggota dan mencari solusi terbaik dalam melaksanakan program kerja bank sampah ini agar menjadi lebih maju. Dalam kesempatan ini, tim inisiator juga memberikan bantuan berupa uang tunai yang dialokasikan untuk pembelian tong sampah. Dengan harapan setiap anggota memiliki semangat yang lebih tinggi dalam mengumpulkan sampah dan tidak dibuang di sembarang tempat yang akan berdampak buruk bagi lingkungan dan sosial ekonomi masyarakat.

Hasil FGD juga mengerucut pada penggalian beberapa informasi diantaranya: pertama teridentifikasinya karakteristik sampah yang pada lokasi Dusun Dekat Agung Kabupaten Lamongan (lokasi di dua RT).

Kedua, informasi mengenai hasil sampah warga yang sudah dalam kondisi terpilah sesuai dengan jenis sampah disetor ke Unit Bank Sampah. Sampah yang sudah tertampung di Unit Bank Sampah dibeli oleh Bank Sampah Deket Agung, hasil penjualan sampah ditabung di Bank Sampah Deket Agung (BDA). Terdapat beberapa ketentuan pelaksanaan tabungan sampah, yaitu: jam kerja, penarikan tabungan, peminjaman uang, 
buku tabungan, jasa penjemputan sampah, jenis tabungan, jenis sampah, penetapan harga, kondisi sampah, berat minimum sampah yang disetor, wadah sampah, keuntungan kelompok binaan dan pemberian upah karyawan.

Ketiga, Jam kerja Unit Bank Sampah di dusun dekat agung berdasarkan kesepakatan para pengurus/ketersediaan waktu pengelola bank sampah, jam kerja setiap hari sabtu jam 10.00 - 16.00 dan hari minggu jam 10.00 - 16.00, Unit Bank Sampah tidak buka setiap hari agar sampah yang disetor warga lebih banyak. Hasil penjualan sampah dapat langsung diambil secara tunai atau ditabung dan dicatat dalam buku rekening tabungan yang dipersiapkan oleh Bank Sampah Deket Agung. Jenis sampah yang dapat ditabung di Bank Sampah berdasarkan data dari Bank Sampah Deket Agungper Agustus tahun 2018 dikelompokkan menjadi beberapa jenis dan masing-masing jenis mempunyai kode, yaitu: 1. Jenis plastik, dengan kode: P1 - P37 dan AK1-AK3; 2. Jenis kertas, dengan kode: K1-K9. 3. Jenis logam, dengan kode: S1-S2, BS1-BS2, A1-A8, KN, T!-T2. 4. Jenis botol dan kaca, dengan kode: B1-B8.

Tabel 4 Jenis Sampah yang Teridentifikasi

\begin{tabular}{|c|c|c|c|c|c|c|c|}
\hline \multirow{3}{*}{ No } & \multirow{3}{*}{ Sampah } & \multicolumn{4}{|c|}{ Sifat Sampah } & \multicolumn{2}{|c|}{ Jenis Sampah } \\
\hline & & \multicolumn{2}{|c|}{ Terbakar } & \multicolumn{2}{|c|}{ Terurai } & \multirow{2}{*}{ Organik } & \multirow{2}{*}{ Anorganik } \\
\hline & & Mudah & Sulit & Mudah & Sulit & & \\
\hline 1 & Botol Kaleng & & $\mathrm{V}$ & & & & $\mathrm{V}$ \\
\hline 2 & Botol Minuman (p) & $\mathrm{v}$ & & & & & $\mathrm{v}$ \\
\hline 3 & Botol minuman $(\mathrm{g})$ & & $\mathrm{v}$ & & & & $\mathrm{v}$ \\
\hline 4 & Kertas & $\mathrm{v}$ & & & & & $\mathrm{v}$ \\
\hline 5 & Gerabah & $\mathrm{v}$ & & & & & $\mathrm{v}$ \\
\hline 6 & Tikar & $\mathrm{V}$ & & & & & $\mathrm{v}$ \\
\hline 7 & $\begin{array}{l}\text { Botol parfum dan make } \\
\text { up }\end{array}$ & & $\mathrm{V}$ & & & & $\mathrm{v}$ \\
\hline 8 & Kardus & $\mathrm{v}$ & & & & & $\mathrm{v}$ \\
\hline 9 & Plastik Kresek & $\mathrm{v}$ & & & & & $\mathrm{v}$ \\
\hline 10 & Sisa Makanan & & & $\mathrm{v}$ & & $\mathrm{V}$ & \\
\hline 11 & Sayuran & & & $\mathrm{v}$ & & $\mathrm{v}$ & \\
\hline 12 & Buah-buahan & & & $\mathrm{v}$ & & $\mathrm{v}$ & \\
\hline 13 & Taman/halaman & & & & $\mathrm{v}$ & $\mathrm{v}$ & \\
\hline 14 & Makanan binatang & & & & $\mathrm{V}$ & $\mathrm{V}$ & \\
\hline
\end{tabular}

Keempat, Penetapan harga setiap jenis sampah merupakan kesepakatan antara pengurus Unit Bank Sampah dengan Bank Sampah Deket Agung. Harga setiap jenis sampah bersifat fluktuatif tergantung harga pasaran. Bank Sampah memberikan daftar harga sampah kepada pengurus dan pengurus menyampaikan harga sampah ke warga atau penabung. Penetapan harga sampah dari Bank Sampah Deket Agung(BSDA): Harga untuk anggota kelompok yang menjual sampah secara kolektif dan mengharapkan uang tunai, harga sampah ditetapkan BSM lebih rendah dibandingkan dengan harga sampah yang ditabung, begitu juga sebaliknya, untuk penabung yang menjual sampah secara kolektif dan hasil penjualan sampah sengaja untuk ditabung, mendapatkan harga sampah lebih tinggi dibanding secara individu.

Selanjutnya, di dalam kegiatan FGD juga diulas mengenai kendala dan harapan anggota 
yang terlibat langsung di dalam pengelolaan bank sampah. Berikut ini dapat dilihat hasil FGD yang dirangkum dari beberapa masyarakat yang terlibat.

Tabel 5 Komposisi Sampah Yang Dapat dan Tidak Dikomposkan

\begin{tabular}{lc}
\hline \multicolumn{1}{c}{ Komponen } & Komposisi (\%) \\
\hline Dapat dikomposkan & \\
1. Buah-buahan & 5,65 \\
2. Sayuran & 9,96 \\
3. Taman/halaman & 2,20 \\
4. Makanan Binatang & 2,37 \\
Sub Total & $\mathbf{2 0 , 1 8}$ \\
Tidak dapat dikomposkan & \\
1. Kertas & 23,33 \\
2. Plastik & 14,20 \\
3. Kayu & 5,39 \\
4. Botol & 18,63 \\
5. Kardus & 18,27 \\
Sub Total & 79,82 \\
\hline
\end{tabular}

\section{KESIMPULAN DAN SARAN}

Kesimpulan

Program pengabdian masyarakat yang telah dilaksanakan di desa Deketagung, Kecamatan Sugio, Kabupaten Lamongan dilakukan untuk memperbaiki kondisi lingkungan serta meningkatkan perekonomian masyarakat desa tersebut. Kegiatan yang telah dilakukan adalah sebagai berikut:

i. Sosialisasi pembentukan bank sampah pada kelompok ibu rumah tangga, lansia, dan janda

ii. Membentuk kelompok-kelompok untuk mengelola sampah di tingkat rumah tangga

iii. Mendesain insetif pertukaran sampah yang bisa didaur ulang.

iv. Menghitung hasil sampah yang terkumpul, evaluasi pencatatan bank sampah, Saran dan Focus Group Discussion (FGD)

Dengan adanya program pengabdian masyarakat melalui pendampingan pembentukan bank sampah di desa Deketagung, diharapkan mampu meningkatkan perekonomian masyarakat desa Deketagung melalui pengelolaan sampah. 


\section{REFERENSI}

Adnan, M. A., \& Ajija, S. R. (2015). The effectiveness of Baitul Maal. Humanomics , 31 (2), 160-182.

Anggraini, D. K., \& Devi, S. (2013). Industri Di Surabaya Pada Masa Pemerintahan Walikota. Verleden , 3 (1), 21-30.

Badan Pusat Statistik Kota Surabaya. (2015). Surabaya Dalam Angka . Surabaya: Badan Pusat Statistik Kota Surabaya.

Badan Pusat Statistik Kota Surabaya. (2016). Surabaya Dalam Angka. Surabaya: Badan Pusat Statistik Kota Surabaya.

Khasanah, K. N. (2016). Kebijakan Kelautan Nasional Sebagai Arah dan Pedoman Pembangunan Kelautan. Dipetik Mei 25, 2017, dari http://nelayansurabaya.com/2016/05/12/kebijakan-kelautan-nasional-sebagaiarah-dan-pedoman-pembangunan-kelautan/ 